\title{
ENDURANCE AND TRANSFORMATION IN LE CORBUSIER'S REDENT
}

\author{
Josefina GONZÁLEZ CUBERO \\ Escuela Técnica Superior de Arquitectura, Universidad de Valladolid, Avda. Salamanca 18, \\ 470014 Valladolid, Spain \\ E-mail: josefina.gonzalez.cubero@tap.uva.es \\ Received 19 February 2016; accepted 22 April 2016
}

\begin{abstract}
The redent is the only generic building of Le Corbusier's to endure and be transformed over the years between the initial and last designs, while others (immeubles-villas, gratteciel cartésien cruciforme, etc) disappeared altogether and still others arose during his lifespan (Unités, gratteciel «patte de poule» or “ $y$ ”, etc). The residential redents's obsessive presence can be attributed to its versatility in composition given that it is both open and closed at the same time. While the open form pools from French military architecture, the French garden, and social reformism, the closed form is highly attributed to Sitte's tradition. To discover its phylogeny rather than its achievements, all one needs to do is go back in time from the stale mechanism used in Hauptstadt-Berlin to the incipient form that was inoculated based on Fröbel's teaching system of learning through play.
\end{abstract}

Keywords: Le Corbusier, modern architecture, urban design, redent, building-type, square, plaza, park.

\section{Introduction}

When Le Corbusier tackled the job of giving shape to modern cities with the aim of graphically enunciating universal, abstract, generic principles, operationally speaking, he established certain initial assumptions or a priori whose roots were steeped in the past. Before assigning solutions to specific problems, he needed to set out his great urban planning on a clean slate. Whatever that clean slate is, it will always have two constant features: the grid (warp) and the filling (weft). It was with this intention that he designed two successive theoretical cities: Ville contemporaine (Contemporary City) in 1922 and Ville radieuse (Radiant City) in 1930. Neither of the two were patterns or models to be applied 'as is', but were rather great theoretical conceptions of city designs with a view to control their definitive form. Their warps varied while their wefts or independent filler portions endured to forge the idea underpinning the new city, similar to the notion of new architecture enunciated in the " 5 points" following Jean-NicolasLouis Durand's "Parts of a Building".

Generic buildings or building-types were the initial assumptions on which the theoretical models of the

\footnotetext{
Translation by Beth Gelb.
}

city were based. They were differentiated, autonomous components related to each other through juxtaposition that was concentric in the Ville contemporaine and linear in the Ville radieuse. Later, urban fabric was dissolved in the "7V Rule" where the parts became mere solitary fragments. There is nothing better than to acknowledge before the fact what one wishes to spare from criticism:

"Si l'on examine de près l'œuvre de Le Corbusier on ne tarde pas à reconnaître que cette abondance n'est pas faite de 'trouvailles' accolées l'une à l'autre au hasard. Les plus curieuses trouvailles ne sont jamais que des éphémères et elles ne pèsent pas lourd. Elles ne peuvent devenir fécondes que si elles servent à développer et à approfondir de plus en plus, dans toutes leurs conséquences, un petit nombre de principes clairement conçus.

L'évolution de Le Corbusier a précisément ceci de persuasif qu'elle constitue la réalisation progressive et pour ainsi dire organique d'une tâche conçue clairement dès l'origine" (Le Corbusier 1934: 9).

Pieter Oud alerted to the juxtaposition used by Le Corbusier (Oud 1986: 126-131), and Allen Brooks had detected it back in 1916 in the conception of the villa for Anatole Schowb (Allen Brooks 1987: 12). However, Le Corbusier clearly states this with few principles and 
by organically developing something whose roots are steeped in history, and which he perused in his years as an intrepid student at La Chaux-de-Fonds. His incendiary cries against neo-historical architecture are a smoke screen veiling the quarry from the past from which Le Corbusier mined to give shape to the parts. And he took it upon himself to pass on this legacy to students:

“Tout à l'heure, vous aviez vu qu'entraîné par la défense des droits à l'invention, je prenais à témoin le passé, ce passé qui fut mon seul maître, qui continue à être mon permanent admoniteur. Tout homme pondéré, lancé dans l'inconnu de l'invention architecturale, ne peut vraiment appuyer son élan que sur les leçons données par les siècles; les témoins que les temps ont respectés ont une valeur humaine permanente" (Le Corbusier 1957).

In conceiving the parts, he employed a very few basic themes that were common to both theoretical urban models. The most significant of them was the open form for mass housing enshrined in the allotments with redents. Their trajectory can be traced because they endured over various gradual transformations. This is the baggage with which Le Corbusier tackled urban designs in specific cases because "L'architecture se fait dans la tête. Il faut arriver à tout concevoir dans sa tête, les yeux fermés; on sait alors comment tout sera" (Le Corbusier 1930: 230). And after having been a recurrent element in his urban designs for a long time, the planning of the allotments with redents reached the International Hauptstadt-Berlin Competition (1958) (Fig. 1).

The competition's aim was to rebuild the destroyed centre and hopefully confer capital status to the city once again. Le Corbusier presented a design that was a compendium of his previous repertoire of urban ideas, generic and specific buildings, either designed or built.
In one of Berlin's most regular areas, he put forward an organization whose main residential woof was primarily composed of allotments with redents, that is to say, portions of space that included pairs of buildings set out linearly with orthogonal folds in a Greek pattern, and this constituted one of the design's generic buildings. Departing from the variations of folds and sliding pairing that had previously been put forward in its genealogy, here the buildings were laid out with a single fold. Like walls, they boxed pedestrians and traffic into different alternating strips while simplifying forms and monotonously reiterating the identical geometry of rectangular urban spaces.

Le Corbusier did not win the competition; nor could he build any redent building over the course of his lifetime. Only his followers were able to build variants in different latitudes, and these variants naturally underwent patent metamorphosis. But redents's longevity should be highlighted since certain building-types did disappear (immeubles-villas, gratteciel cartésien cruciforme, etc.) while others arose over the course of his life (unités, gratteciel «patte de poule» or "y", etc.). This demonstrates his faithfulness to this emblematic form in his architectural production. The HauptstadtBerlin redents mark both the designer's attachment to the formal generation system and its ossification.

In short, in Berlin, the Ville radieuse's redent ideal of unlimited linear extension and total permeability with land planned for man in communion with nature in residential areas dissipated. The endurance of these open and highly adaptable forms, apprehended from the French tradition, bears witness to Le Corbusier's reluctance to fully renounce the bequeathal of closed space, defined by Camille Sitte, instead of supporting the continuous linear growth which is consequence of the modern, technical reproducibility. It would be

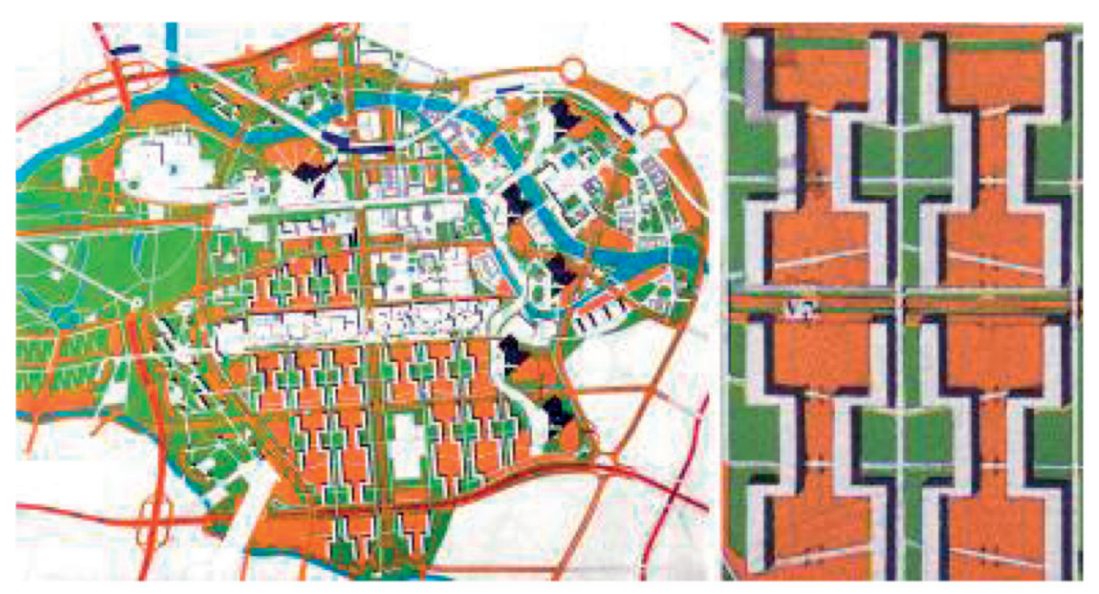

Fig. 1. Le Corbusier. International Hauptstadt-Berlin Competition, 1958. General plan and detail of the redents [FLC] 
unfair to assert that the redent was spent or lacking in interest because all one needs to is travel back in time to discover, rather than its achievements, its phylogeny.

\section{Continuity versus fragmentation in residential redents}

If Berlin was a compendium it is because in the 1940s Le Corbusier took stock of the architectural forms that had been created over time. In Cuvre complète 193846 he classified the types of buildings for accommodation into redents (Le Corbusier 1946: 151), "Ys", frontals, spines and staggering ${ }^{1}$, and buildings for business into "Ys" and lens form buildings, though a drawing of a third spine-shaped office building appeared in Manière de penser l'urbanisme (Le Corbusier 1984: 77). With the exception of the redents, he termed all of the others Unités, and only built one such spine typology in Marseille (1945-49), Nantes-Rezé (1952-53), Briey (1957-61), Berlin (1958), and Firminy (1967-68), and in all of these instances, horizontality predominates. Le Corbusier was never to build an exclusively residential skyscraper and only very late in his career did he put forward the cylindrical apartment tower for those living on their own in one tower design in Strasbourg (1951), two in Marseille-Sud (1951) and Meaux (1956), and several in Berlin (1958). This typology played the role of an extra among the other housing blocks and was not used in a group until the Berlin proposal.

Like Alfred Louis Kroeber's trees (Fig. 2), the residential branches were interpaireded but preceded by diversification ramifying from the same trunk. The Unité and the skyscraper influenced each other. An example can be found in the Cartesian patte de poule skyscraper - Barcelona (1932), Antwerp (1933), Geneva (1933) and Buenos Aires (1938) - which he considered on his trip to New York in 1935 as a container for both offices and apartments in order to optimize
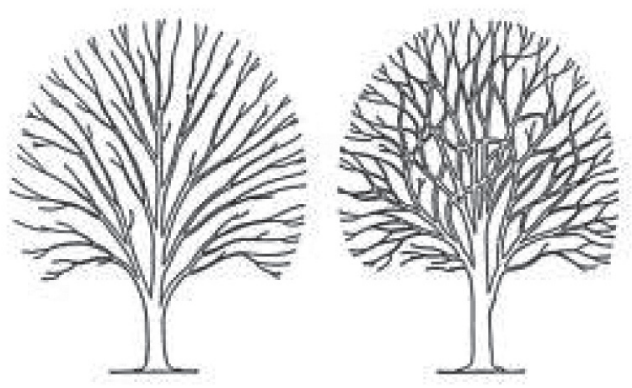

Fig. 2. Alfred Louis Kroeber (1876-1960). Trees of biological and cultural evolution (Kroeber 1948)

\footnotetext{
1 The staggered type for accommodation does not appear in Manière de penser l'urbanisme (Le Corbusier 1984: 72).
}

profits on Manhattan's land. Le Corbusier also designed Unités with lens shaped floor plans that were later to determine one of the possible shapes for skyscrapers, such as in Algiers' Marine quarter which has two lens shaped administrative buildings. The patte de poule shaped Unité can be found in the Bastion Kellermann (1934-35), an urban development in the northern outskirts of Rome (1935), in Hellocourt in Loraine (1935), in Addis-Ababa (1936), in Rio de Janeiro (1936), in Algiers (1942) and in the original proposal for La Rochelle-Pallice (1945-46).

This succinct itinerary shows how the type volumes could be indistinctly grouped into administrative and residential cells. The administrative buildings could either be high-rises or horizontal while the residential buildings were built exclusively horizontally. Is it outlandish then, to think that the Unités - be they spine shaped, patte de poule, or what have you- and the last redents are just different branches stemming from the same common redent trunk?

The taxonomy of the Unités built displays an obvious prevalence of the building as an object. Their plastic power of attraction resides in their oneness. Yet it originates in automatic repetition. That is the model on which it is based. The eight Unités in the Saint-Dié development (1945) attest to numerical reproduction just as their position across the great avenue attests to their plastic achievement. The reading of the Unité as an interval stripped from the redent building is reinforced by the use of the same type of apartment and by the incongruity of lifting it up onto pilotis to foster pedestrian circulation when it is an isolated building in the park. Therefore, the lonely, melancholy Unité d'habitation is the descendent of a two-aisle redent with a central corridor and an East-West exposure. This is why, in the minds of some authors, it marks the last transformation of the city block (Panerai 1986: 139).

If we continue to go back in time, we find the seed of the residential building's isolation. The Paris Plan (1937) contains a business centre and three specific residential interventions encapsulating the work that had been done thus far on housing. The Îlot insalubre $N^{\circ} 6$ (1936) exemplifies the rupture with the orthogonal redent (Fig. 3). The preliminary studies for the 4000 inhabitant Bastion Kellermann Unité (1935) exemplify the fragmentation of the curved redent's continuity, and Project $A$ to develop part of the Bois de Vincennes and build the Exposition Internationale de l'Habitation (1932) harks back to the original redent's continuity.

The Îlot Insalubre $N^{o} 6$ redent was conceived to be inserted in Paris' urban fabric and was related by Sigfried Giedion to Nash's first Regent's Park design (Giedion 1982: 787). The orthogonal pattern of the 
redent arises in the park on torturous terrain hampering intervention, beside the East-West thoroughfare defended by Le Corbusier. The outcome can be intuited by the fact that the intervention is divided in two. Each of the two portions is interrupted by segments with large openings over a continuous base like the redents in the Ville radieuse (FLC 30836, 30837 and 30838 (25-9-1936)) (Fig. 4). Vacillations are denoted by the mismatch in the allotment between the floor plan and the perspective (FLC 22829) (Fig. 5). In the view, the section's open spaces are enclosed walkways on the last floor with steps to mitigate the impact of imminent segregation into laminar portions, and this detail was removed from the floor plan.

Illot is not the only instance in which the redent is fragmented. The same holds in the Zlín development (1935) where this can be perceived vis-à-vis the body while there is continuity at the base (Fig. 6). The layout of the paired structures, without repeating the same modules, encapsulates a sequence of spaces similar to that of their predecessors, symmetrically strung together along the main thoroughfare. This is the single feature that is carried over from the previous street configuration. What is salient about the design is that the redents on the flat terrain co-exist with the spine Unités on the valley's hillsides. This same type of residential unit was used in L'Oued-Ouchaia in Algiers (1933-34) and in Nemours (1934).

The residential Unité for Bastion Kellermann underwent two interesting phases before becoming a patte de poule volume: first, a curved redent (FLC 22847) and then a laminar building-bridge (FLC 28361) spanning the dip in the terrain and the Gentilly cemetery. The residential buildings and streets are uniquely tied together and, each in its own way, are reminiscent of the redents in South America and Algiers. The former has a curved shape and the latter links streets and housing infrastructure to adapt to the sloping down of the terrain. Lastly, in a twist of irony, the patte de poule shaped Unité stands in the opposite direction of the bow of an archaeological salient of the old Paris fortifications.

As an emblem of Projet $A$ for the Bois de Vincennes (Fig. 7), Le Corbusier applied a sector coming as an epigon to the Ville radieuse. It was made up of two base modules of the paired residential redents symmetrically facing each other. The arabesque was closed off on its ends, thereby generating enclosed cross-shaped and rectangular inner areas functioning like alveoli thanks to their wooded fragments. The area establishes the orthodoxy of the radiating redents while its enclosure even further stresses, if possible, the notion of a concatenation of large park-squares.

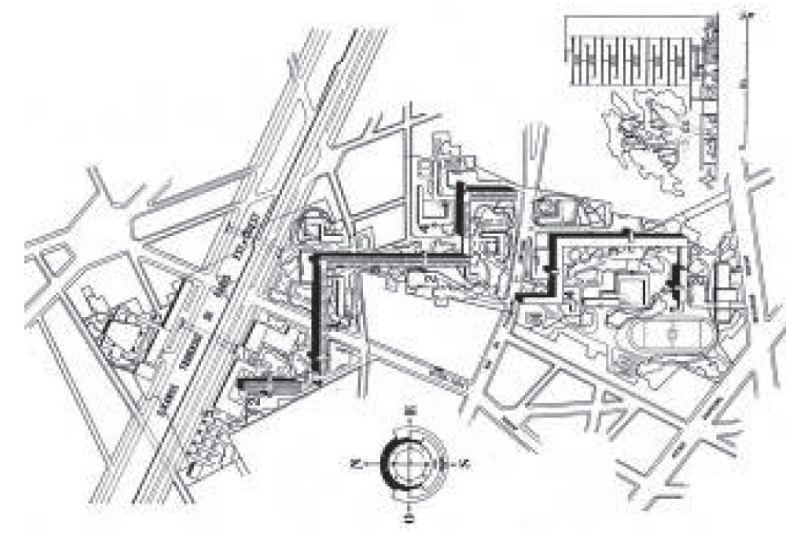

Fig. 3. Le Corbusier. Îlot insalubre No6, Paris, 1936. Plan (FLC)

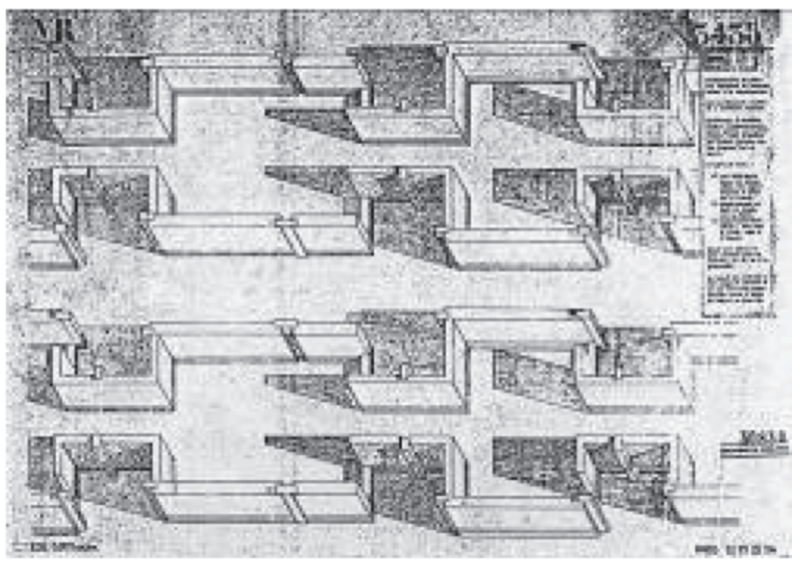

Fig. 4. Le Corbusier. Ville radieuse. Sketches of redents, 25-91936 (FLC 30838)

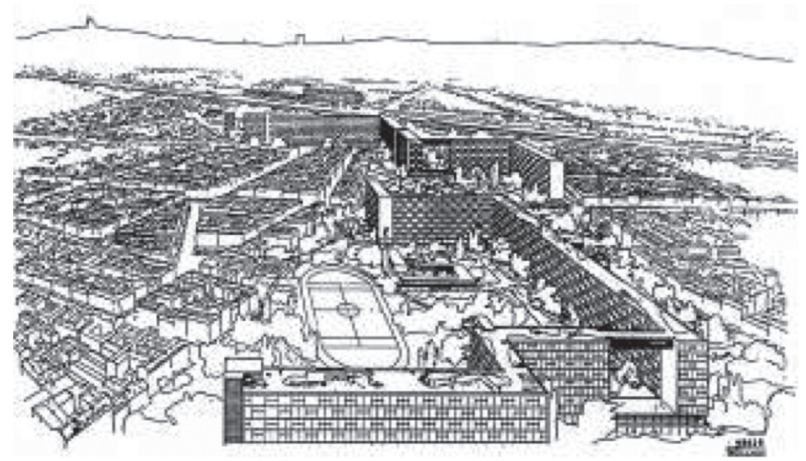

Fig. 5. Le Corbusier. Îlot insalubre No 6, Paris, 1936. View of the redent (FLC 22829)

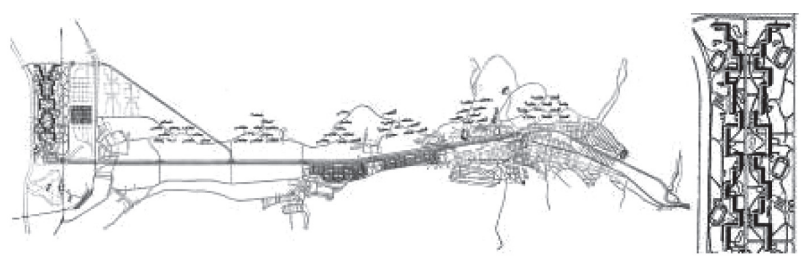

Fig. 6. Le Corbusier. Urbanisation of Zlín (Bata Corporation), Czechoslovakia, 1935. General plan and detail of the redents (FLC) 
Before the Unités became widespread for housing, during the 1930s, Le Corbusier chose redents for residential neighbourhoods in urban planning projects such as Porte Maillot (1929), Antwerp (1933), Geneva (1933), Stockholm (1933), Barcelona (Plan Maciá, 1933), Zlín (1935), Boulogne-sur-Seine (Pont de St. Cloud, 1938), etc. Though obviously not endless, the redents

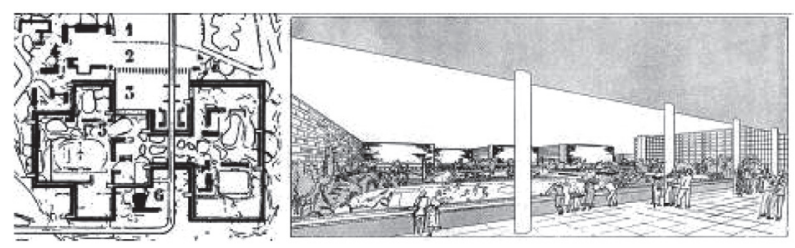

Fig. 7. Le Corbusier. Project A, Exposition Internationale de I'Habitation, Bois de Vincennes, Paris, 1932. Plan and view (FLC)

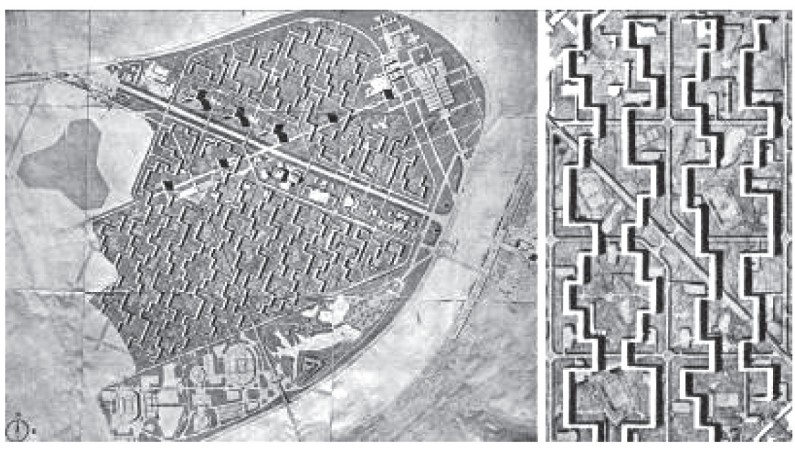

Fig. 8. Le Corbusier. Antwerp, 1933. General plan and detail of the redents (FLC)

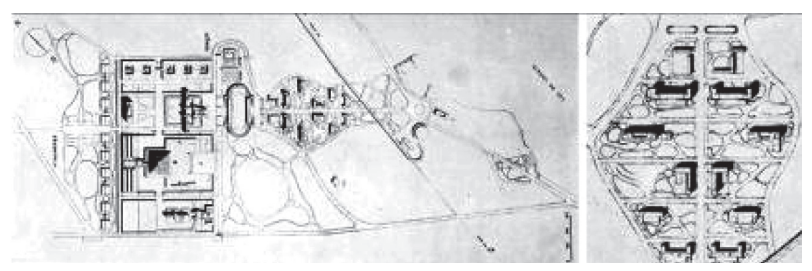

Fig. 9. Le Corbusier. Cité Mondiale, Geneva, 1929. General plan and detail (FLC)
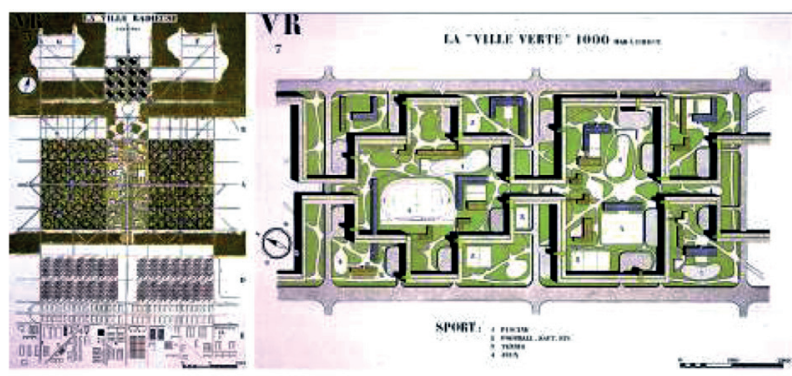

Fig. 10. Le Corbusier. Ville radieuse, 1930. General plan (VR 15) and sector (redents) (VR 7) (FLC) are continuous such as in the Ville radieuse, and are able to conserve their symmetry or even be displaced in relative terms, or both, as is the case in Antwerp (Fig. 8). The compositional model spawns a host of permutations depending on the specific conditions in each location, and all of this attests to its flexibility and adaptability.

It is true that Le Corbusier defended high-rise residential buildings in cities, as he did with Gropius in the third Brussels CIAM (1930). Nevertheless, they are always laminar and horizontal. The genesis of fragmentation in mass housing was assayed in the hotel and residential complex accompanying the Mundaneum design (1929) in Geneva (Fig. 9). It was made up of laminar buildings set in the park perpendicularly to the thoroughfare in order to obtain a given texture of light and shadow. This plastic effect is something Le Corbusier sought constantly, even when the redent's continuity was interrupted, and is an echo of Hénard's boulevard à redans that seduced the young Jeanneret.

\section{The continuous residential redent: closed vertically, open horizontally}

The Ville radieuse (Fig. 10), at the acme of Le Corbusier's theoretical investigation, symbolizes equalitarian social ambitions gleaned from utopic French reformers ${ }^{2}$. But as a reformative architect, Le Corbusier, under the influence of Soviet disurbanism, turned to a point of reference from his youth, Madrid's Ciudad lineal (1882) designed by Arturo Soria y Mata (Brooks 1985: 40-51), which he studied in the National Library in Paris in 1915 and was later to craft into a decentralized, radiating model with real linear movement and, above all, linear growth in its forms.

By following these parameters, he organized the accommodations in a large linearly expanding band comprised solely of continuous redents, all of which stood on pilotis. The band was inserted into a biological structure and related to other constituting urban portions and it can be correctly be termed the body or trunk of the organism. Acoustic landscape-oriented shapes arise from his experience in South America and Algeria. Free of geometrical impositions, the redents were set gently yet imposingly on the city as it was. The sinuous redents find their counterparts in the dynamic orthogonal zigzag set in a sea of greenery in the Ville radieuse [VR 15], a direct translation of the Ville verte designed for Moscow.

For the first time, a right-angled zigzag configuration was built on the two alternate base-modules

2 Henri Focillon equates him to Saint-Simon (FLC B2-16-178, B2-16-179). 
with both single and double orthogonal folds [VR 1]. Their relative linear shifting and way in which they face each other generates a residential combination with greater spatial variety. Therefore, by changing their relative position of these same elements, visual variety was enriched through a sequence of squareparks. Nevertheless, when approaching the buildings' scale, Le Corbusier represented paired redents in a portion called a sector [VR 7] in their original position, which is most similar to its roots from the past. These modernized replicas of the ramparts confer the same defensive capacity to face modern war that, according to "la guerre aérienne" [VR 17] (Le Corbusier 1935: 60-61), could only be faced by cities conceived on the Ville radieuse model.

The sector included the two alternate base-modules, with symmetrical pairing generating a cross shape and a rectangle. They are shallower and shorter than the redents in the Ville contemporaine. Here the segments on the folds are not juxtaposed, and the continuous volume rotates to form dihedrals. But at the same time, the sun dictates the exposure of the sector and the city as well as the thickness of the building in certain sections depending on whether it functions as a lateral or central corridor. It also determines the urban image generated by the combination of the glass panels' (pan de verre) transparency and the opacity of the perforated façade walls.

Since the Ville contemporaine, the $400 \times 400$ metre street grid has often worked as an assistant and, because the redent's two base-modules have different interval dimensions, they are able to become independent from each other and can be understood independently. This enables them to conceal the underlying checkerboard pattern of the city under which the redents stand, but which Le Corbusier did not destroy because he was attached to it since his early childhood (Solitaire 1993: 114). The grid became specialized with different width streets and no streets with traffic were set between the paired redents. This freed up land to be used as a continuous park spanning out to the contours of the city over diagonal walkways that cross the roads in underpasses. In short, the redent became independent and shifted along the grid while the streets were split and specialized generating true independence between the home and the street.

The park, dotted with schools and sporting facilities to avoid axial views, also took on autonomy vis-à-vis the architecture. It served to mediate between man and the great zigzagging colossuses. One can truly say this was a city in a park (González Cubero 2004: 75-76). And the park, together with the scale of the edification and the apartment blocks' weightlessness are the fac- tors that lead the thread of the redent's enclosure to be lost. It is the enclosure that acts as a great centripetal force providing cohesion to this very special space, the last bastion of the traditional city. Le Corbusier turned the (plaza) square-park into the park-(plaza) square.

\section{The redent's testing laboratory}

For Le Corbusier, the 1920s was a period of immersion both in mass housing and the challenge of large scale urban planning. He debuted with the Ville contemporaine and verified its applicability in the Plan Voisin (1925) for Paris (Fig. 11). With the intention of relieving the crowded urban centre, Eugène Hénard's “boulevard à redans" formulated in the second fascicule of Etudes sur les transformations de Paris published in 1903 (Hénard 1976: 61-79), had raised this possibility as a solution for Paris. For this purpose, a third ring road was prepared for Paris. It was to be a major thoroughfare $^{3}$ on the terrain that was freed up where the ramparts had stood. The military architecture terms, i.e. boulevard and redan, were maintained to designate this freed up urban space and the new buildings replacing and imitating them. The fortifications, based on military strategies, were reproduced in the new interventions and their configuration became a principle used in composing spaces and buildings.

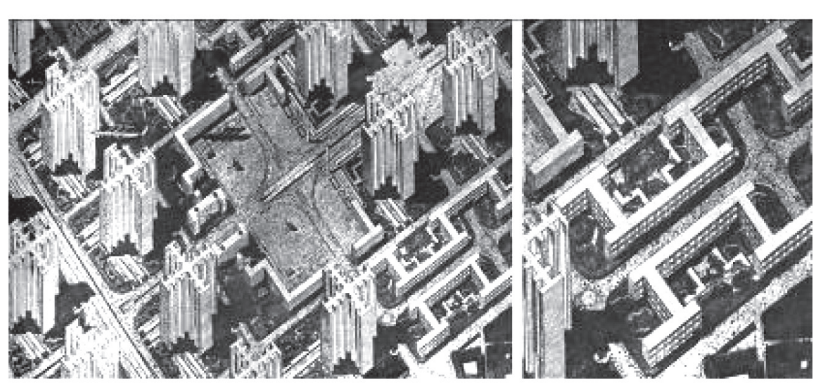

Fig. 11. Le Corbusier. Plan Voisin, 1935. General axonometric view and detail of the redents (FLC 29723)

The redents made their comeback in Paris thanks to Le Corbusier who maintained their original adaptability and suited them to the deformed geometrical warp in two different ways (Cohen 1987: 34-41). For one, he used irregular patterns set out at whim. Oftentimes they were very closed in order to conserve significant historical buildings. Also, he used regular single orthogonal fold patterns located very near the great skyscraper forum. As had been the case until then, both of these patterns were reproduced by juxtaposing seg-

\footnotetext{
3 According to Giedion, Paris' first boulevards in the 17th century were footpaths and not streets for heavy traffic as were Haussmann's later boulevards (Giedion 1982: 696-697).
} 
ments that were displaced, slightly protruding at the corners. The residential buildings specifically have to do with the lotissement à alvéoles allotments for the garden cities (Fig. 12).

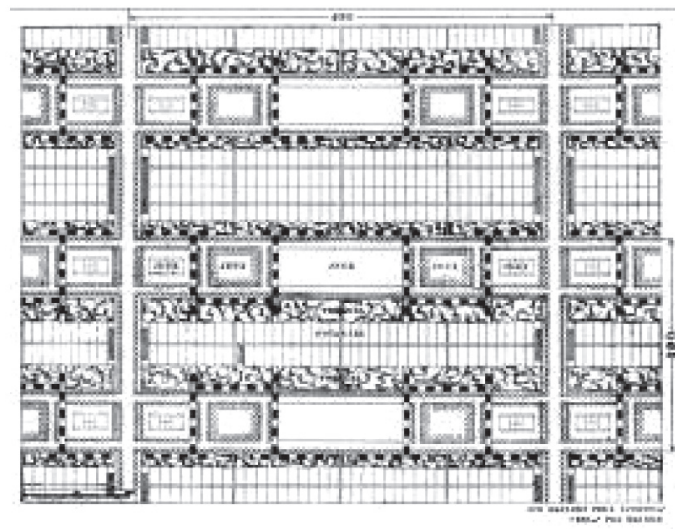

Fig. 12. Le Corbusier. Lotissement à alvéoles for garden cities. Plan (FLC)

The alveoli allotments, produced from parcelling out cultivated land, sprang from an "attitude éminemment architecturale" (Le Corbusier 1925: 197) and were considered by Le Corbusier to be the continuation of the immeubles-villas (Le Corbusier 1929: 76). What makes them similar to the redents in the Plan Voisin is their simplicity given they have a single orthogonal fold. However, in Paris, the dominating segments on the links run parallel to the streets, while in the allotments with alveoli they can be found in both directions.

Two different variations of the redents appear in the Plan Voisin. There are those which have the villa alveoli plots drawn on both sides and which therefore are residential, and those planned for administrative use whose façades are structured in horizontal strips suggestive of the horizontal Dom-ino space, slightly narrower than the others and located near the most emblematic urban areas. It can therefore be asserted that the dual residential and administrative use of the redents, and later the dual use of the patte de poule for both the Unités and the office skyscrapers, disproves Françoise Choay's assertion that: "each prototype has its use" which "expresses the truth of the function" (Choay 1970: 49).

The plan and axonometric view [FLC 31007] of a generic 400x600 metre lotissement à redents with a double orthogonal fold or a cross shape was published in Urbanisme (Le Corbusier 1925: 222-223, 226-227) (Fig. 13) and adds detail to the Ville contemporaine. The usual composition with segments is maintained while the layout differs from those designed in the Plan Voisin. In the lower portion of the axonometric view, façades with alveoli are specified. They are made up of villas on both sides and encompass six double-stories. This is made possible by juxtaposing $\mathrm{L}$ section apartments around a central corridor. This same mechanism would later give rise to the Unités. If one bears in mind that the Ville radieuse redents have one story type apartments, unlike the initial duplex apartments, [VR 19], then one can see that the typology of the residential cells is divorced from the building's shape thanks to the fact that it can accommodate a range of interchangeable 'types'. The building is thus not the result of association but rather intent regarding the ensemble's shape and image.

The redent published in Urbanisme (Le Corbusier 1925) falls within four major arteries straddled by the buildings in their linear layout. This was taken further when the apartment blocks were lifted from the ground and set onto pilotis in the Ville radieuse. The remainder of the design stands directly on the ground, as it does in the Ville contemporaine and the Plan Voisin. The shield-like role of the buildings generates an interior space while the allotment is divided in two by the street running through the middle. Pedestrian traffic remains limited to a single direction across the allotment crossing the central street and the parallel streets in underground walkways linking the green areas that, for the first time, enshrine the full picturesque irregularity of a garden. The freedom of movement amidst the vegetation contrasts with the tree-lined streets, thus compartmentalizing the space in a gesture inherited from the bosquets of French gardens.

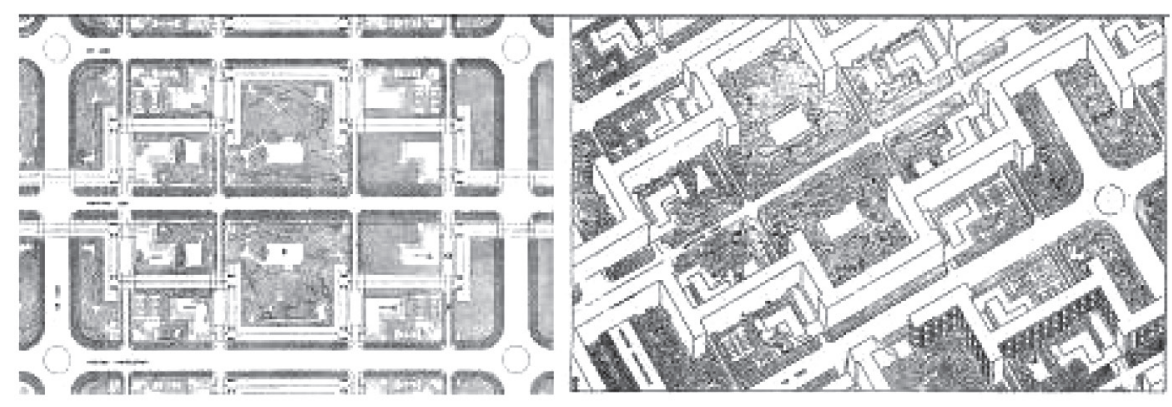

Fig. 13. Le Corbusier. Lotissements à redents, 1925. Plan (FLC 31004B) and axonometric view (FLC 31007) 
The Ville contemporaine's general plan (1922) arose when the buildings were fairly defined in terms of their shape and proportion (Fig. 14). Here, we must remember that although he never mentioned it in his publications, Le Corbusier knew Hénard's work, particularly the boulevard à redans design that he had drawn in his youth in the National Library in Paris, and that his teacher Perret had also reminded him of because Perret also had Hénard's work in mind in his first sketches of the building on Franklin Street (Gargiani 1993: 222, 234). Hénard and Perret never faced the challenge of designing a complete city. Given the scant time at his disposal among other reasons, Le Corbusier took up the task and resorted to the main systems found in the French garden.

Le Corbusier defined the city as if it were a garden following the guidelines in the treatise of Dézallier d'Argenville's La Théorie et la Pratique du Jardinage from 1709 (1972: 58), whose plays on parterres he had drawn in the National Library, and on the treatises of Abbey Marc-Antoine Laugier Essai sur l'Architecture published in 1753 (1979: 222, 223) and Observations sur l'architecture published in 1765 (González Cubero 2004: 72-75). The great axial paths and the grid stemming from the French garden confer regularity to the urban ensemble while the so-called "English garden", provides variety in the parts. Superimposed, these two systems bring about a new synthesis (Álvarez Álvarez 2007: 348-349), the one that constitutes Le Corbusier's park, in which he inserts the redents from the Ville contemporaine.

The origin of the Ville contemporaine and its components can be found in the Carnet La Roche (1920-22) preparatory sketches (Fig. 15). The first design [p. 40 (back)] is a single redent that Le Corbusier had designed in 1921 and ruled out in favour of an elongated redent drawn with measurements [p. 41]. The redent has a double orthogonal fold and overlapping segments very similar to the cross-shaped intersections on the streets along the perimeter of the immeubles-villas and the links between the blocks which are timidly insinuated here at one end. Next is a fragment of the city [p. 41 (back)], made up of immeubles-villas and blocks with redents superimposed on a $400 \times 400$ metre grid that is to define the city. In an imitation of royal French squares, it highlights the parallel treelined streets punctuated by landmarks central to the redents to heighten perspective ${ }^{4}$. Between the streets, the orthogonal folds of the redents are introduced onto

\footnotetext{
4 A similar detail is shown in the preliminary view of the Ville contemporaine redents (FLC 30851) that contain large squares crossed by streets dotted with commemorative columns.
}

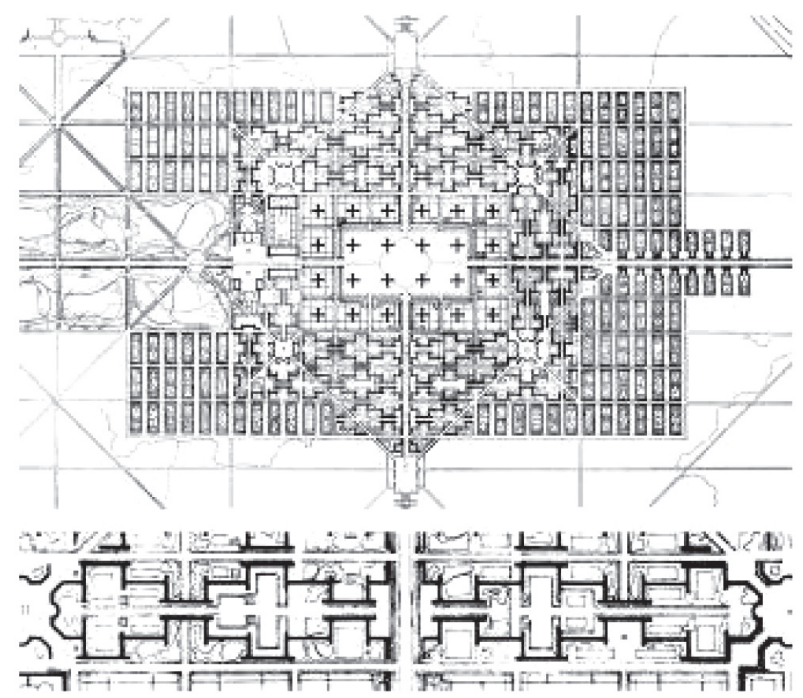

Fig. 14. Le Corbusier. Ville contemporaine, 1922. General plan and detail of the redents (FLC)

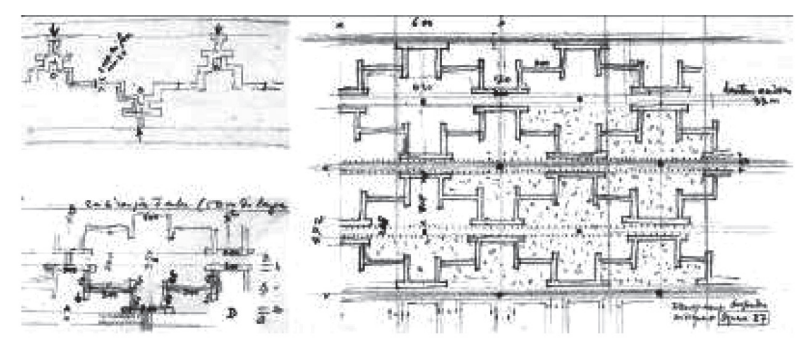

Fig. 15. Le Corbusier. Carnet La Roche, 1920-22. Redents, p. 40 (back), 41 and 41 (back) (FLC)

homogeneously dotted nature foreboding the expanse of the Ville radieuse park.

Again, the Ville contemporaine's permanent grid coincides with the Carnet La Roche's 400×400 metre mesh. On a building block scale, the directions parallel to the redents are clear-cut, while the perpendicular streets seem to dissipate amidst the inner bosquets. The straddling of the redents over the roads directly alludes to the La Percée du Palais Royal in Hénard's Paris Grand Croisée. The linear Greek pattern comprised of a base-module with a double orthogonal fold and juxtaposed segments, alternates with roadways. The buildings are laid out symmetrically with the road axis as their reference. But later, in the Ville radieuse, where the streets were placed alternately between paired redents, the enclosure was separated from traffic.

The counterpoint to the immeubles-villas's linear trench-like street comes from the airiness of the central road between the stepped apartment blocks. This dilation, reflected in the perspective (Fig. 16), is far and above their relative proportions in the city's plan. The new public space results from the moulding 


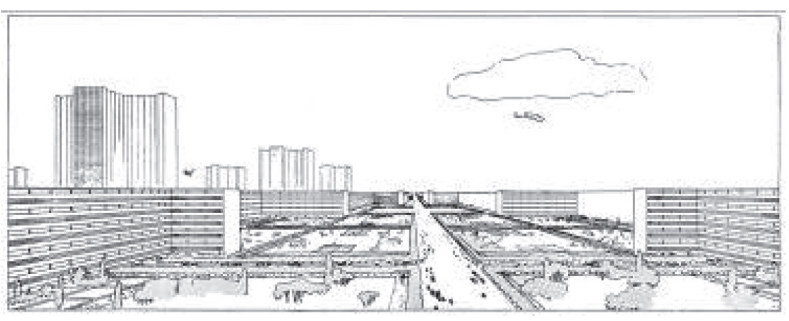

Fig. 16. Le Corbusier. Ville contemporaine, 1922. View of the redents (FLC)

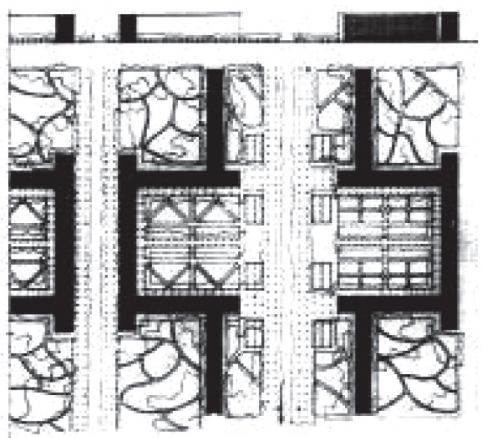

Fig. 17. Le Corbusier. Système préconisé (1921-22) (FLC 30853 Detail)

of the apartment blocks facing each other, following the traces of he Place Vendôme, that was to be camouflaged in the Plan Voisin's redents. The Ville contemporaine's redents gave rise to a large square with only a horizontal trace left by the street. Street and square (plaza) separately were thus transformed into a new street-square (plaza) entity ${ }^{5}$.

Le Corbusier assigns a compositional role of its own to the nature where people pass through and disseminate. The city is set into a park with both regular and irregular gardens. "Les Tuileries pourront s'étendre dorénavant sur des quartiers entiers, jardins français, jardins anglais, géométrie des architectures" (Le Corbusier 1925: 224). This is the architecture that is represented par excellence in the enclosed Palais Royal. With its inner gardens this admired example, contrary to Collin Rowe's assertion (Rowe 1981: 86), was also used by Le Corbusier in his own way in the redents.

The same holds for Laugier's enunciations on the order and variety of neighbourhoods (Laugier 1979: 224, 312-313) that Le Corbusier interprets in his own way, as can be verified in his blend of the two Laugier's texts (Le Corbusier 1925: 65). Hénard and Laugier's notions of variety drive this geometrical arena containing picturesque vegetation and, above and beyond hygienic fac-

\footnotetext{
5 On his trip to Germany following Sitte, Le Corbusier drew on the back of postcards some examples of street-plaza as Herrenstrasse and Rödergasse in Rothenburg (De Simone 1989: 65).
}

tors, offering telling aesthetics and a visual symphony (Le Corbusier 1925: 224). The feeling conveyed by the long redents, either to those driving through or to pedestrians, suggests openness and a vanishing point. In the guise of giant open-air rooms strung together like beads on a necklace, the consecutive closed spaces dilate as squares would and contract like streets. The feel changes when driving along the perpendicular streets on the overall grid as the movement perforates the succession of screen-like apartment blocks. The view when looking towards the redent is reminiscent of a streetsquare, while crossways it seems more like a square. A powerful visual counterpoint drives these two different stagings of the urban landscape (Le Corbusier 1925: 221) where the notion of limitation can be found amidst the immensity.

The so-called Système préconisé (1921-22) (FLC 30853 Detail) (Fig. 17) is included in the documentation produced for the Ville Contemporaine. Though initially ruled out for publishing purposes, it was later reproduced in L'Esprit nouveau 23 (1924) and Urbanisme (Le Corbusier 1925: 94). The system is made up of a pair of orthogonal fold redents set out symmetrically vis-àvis the central, tree-lined street, without straddling the streets on the perimeter. Its significance lies in the step towards a layered appearance and the visibly explicit segment composition of the redent. This endured until it was modified in the Ville radieuse.

The building's dilations trace out a large rectangular area containing gardens divided into a series of enclosures separated from the street emulating the Versailles bosquets. The dependency between building and garden is more mitigated than in the Ville contemporaine. Although the redent is an open form, both the transversal symmetry of the regular gardens and the depth of the orthogonal folds in the buildings enhance the space's concavity while the irregular garden's zigzagging pushes out towards the edges. But in the Ville contemporaine, the irregular garden finally prevails and spreads across the entire plot of the redent. This archaic look harks back to the redents in the earlier versions of its central core, as seen in the preliminary perspective (FLC 30851). Because it is substantially similar to the Palace of Versailles and the Fourier Social Palace, it is unsurprisingly the "defended system" in several senses.

For Le Corbusier, the perfectly functioning ideal community (Teyssot 1981) always has to do with its physical construction. In other words, it must always lie within a building and the building must be a reference point. This harks back to the Charterhouse, although according to the rules of the religious order community life is actually limited to very short periods of time. Another closer reference, both in time and culturally, is 
Charles Fourier's Social Palace or Phalanstère (Serenyi 1975: 103-116), which Le Corbusier mentions twice ${ }^{6}$. The closed world of the Charterhouse that could be intuited in the first immeubles-villas has its equivalent in the Phalanstère in terms of the redent, which represents like none other the slogan "Une maison, un palais"(Le Corbusier 1928).

The commune building's impact goes beyond the notion of social structuring to encompass both interior and exterior formal aspects. For Fourier, the need to link the various portions of the building under shelter hampered the generation of even the slightest harmony within the monastery (Fourier 1980: 81). Neither the monastery at El Escorial nor the Palace of Versailles nor any of the great buildings of the past served as a model for him (Fourier 1980: 79). Yet when Victor Considerant drew it in 1834 based on Fourier's description, he drew inspiration from Versailles (Fig. 18). The building, while containing courtyards in its interior, has its general folded shape extending outward like arms. Le Corbusier was never to consider Perret's “vertical Phalanstère" and would remain more faithful to the open, horizontal apartment block then to the tower.

The rues à redents (1921) (Fig. 19), published in the L'Esprit nouveau 4 (1921) and in Vers une architecture (Le Corbusier 1923: 46), brought both the content and the terminology of Hénard up to date. From the boulevard à redans it moved on to rues and finally to lotissements à redents. Here, the redent was characterised by a thin linear block like a backbone to which crossshaped volumes interrupting the block's continuity were attached on both sides in staggered pattern. The succession of these built bows and hollow garden areas (that he called baies), symmetrically laid out along the streets axis, generates a chain of spatial units appearing like squares and, due to the presence of the street and the organization of the garden, conjuring up the notion of a boulevard. The fact that it applies the same compositional recourse to the both of its sides is what makes it substantially different from Henard's redan.

Le Corbusier adopted Hénard's redan idea very early on, even before using the name. The Dom-ino allotments arose from the determination to overcome the individualism that is part and parcel of the suburban garden city and put forward larger architectural units (Fig. 20). Thanks to the Dom-ino construction system, a grouping could both be conferred with unity and made distinct, and this for Le Corbusier was its greatest advantage. The geometric regularity of the buildings and

\footnotetext{
6 Le Corbusier (1984: 45, 93-94). Also in Le Corbusier (1950: 16), 7 J. Labadié. Les cathédrales de la cité moderne, L'Illustration, LXXX, 12 August 1922, n. 4145, 135. Cited by Gargiani (1993: 237).
}

ensembles' right angles came as a counterpoint to the whimsical irregularity of the roads.

The folded lines of houses are similar to the small schools set between the towers in the sketch contained on one of the pages of the Carnet 1915 and based on Perret's comments on the idea of a free street or rue à redans (Fig. 21). The associated note alludes to the

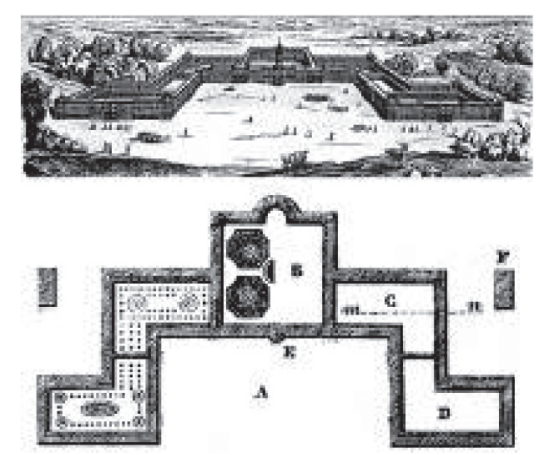

Fig. 18. Charles Fourier. Phalanstère, drawn by Victor Considerant, ca 1834

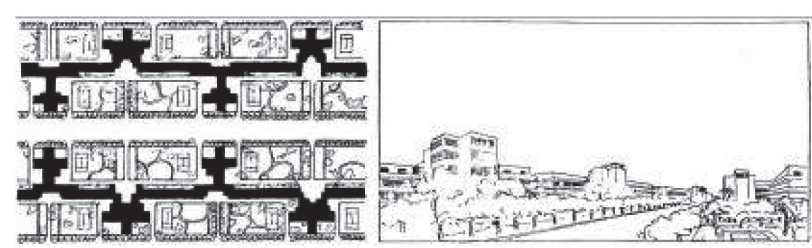

Fig. 19. Le Corbusier. Rues à redents (1921). Plan and view of the redents (FLC)

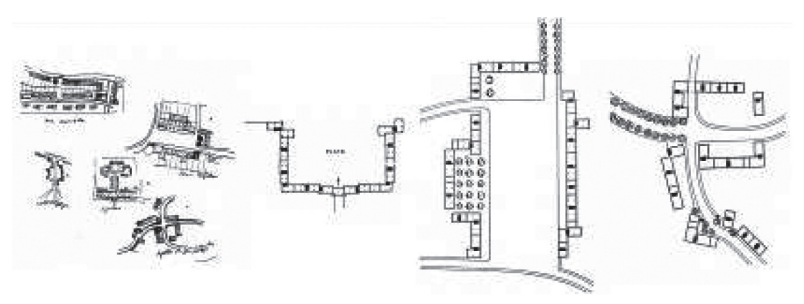

Fig. 20. Le Corbusier. Lotissements Dom-ino, 1914-15. Preliminary sketches and final designs (FLC)

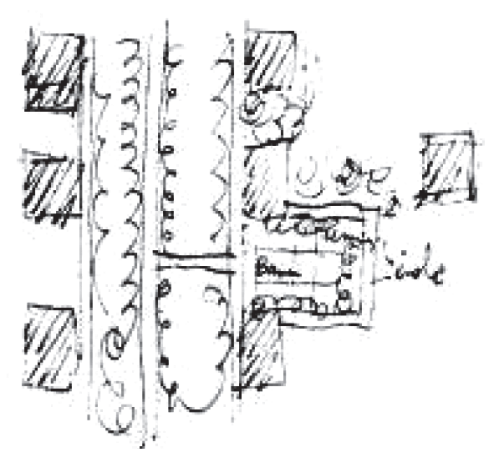

Fig. 21. Le Corbusier. Carnet 1915. Drawing of street à redans according to Perret (FLC) 


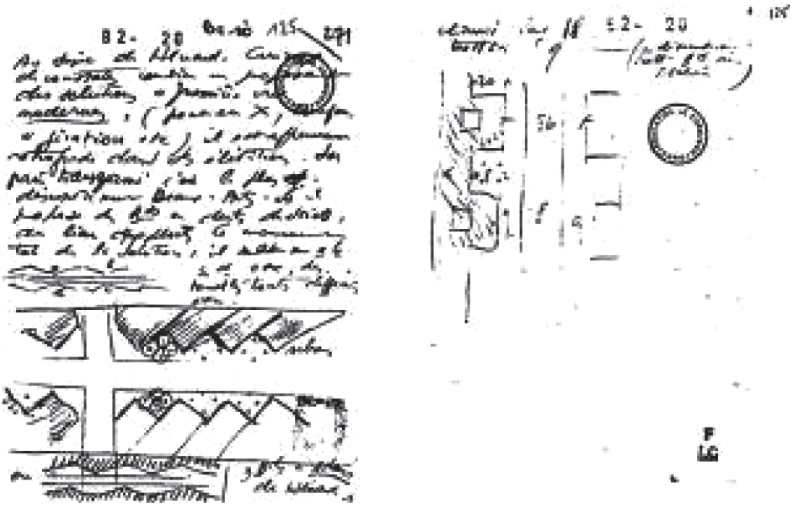

Fig. 22. Le Corbusier. Notes on the Boulevard à redans and Boulevard à redans triangulaires by Hénard (FLC B2-20-125 (10-8-1915)), BNP

redents that were to come later: "L'architecture ne sera plus à infinis détails mais à grandes lignes organiques» (Le Corbusier 1981: 90). His mentor's comment may have unleashed in Le Corbusier the desire to get more information on Hénard, because he was to draw Hénard's designs in the Paris National Library's Cabinet des Estampes in the summer of 1915 (FLC B220-107 (10-8-1915)) (Fig. 22), the same year as the Domino were dated.

What is true is that calling the system after of the game of dominos once again ties into Hénard who, when discovering the boulevard à redans triangulaires (Hénard 1903: 70), a variant of the boulevard à redans, mentioned the shadow and light effects of the dominos placed vertically before an expectant player. Yet Le Corbusier sees the snaking form of the dominos on the board when conceiving the system. Nevertheless he maintained both their forms and their plastic effects in his future redents.

\section{The redent's origins between open and closed forms}

As his references for the iconic process to configure the mass housing Le Corbusier's used the Charterhouse, the Phalanstère and transatlantic ocean-liner. Rather then dwelling on these broadly studied examples, it is worth examining why he pooled mainly from these three sources of information. To say that they are voluntary associations with their own objectives balancing the individual and groups seems incomplete. Another common denominator would need to be added, and that is their lack of belonging to a place. They are generic types of organization whose containers had already been conceived before they came to be built in a given environment. They are standard constructions for religious, social and technical buildings providing the proper medium for the prescribed fraternal society.
Coupled with this lack of being ascribed to a specific place, we can add the redent's dual open and closed condition, straddling the two. Its lineal expansion in a flexible layout able to adapt to different cellular units confers it with modernity. This does not mean that Le Corbusier necessarily fails to develop the redent with internal references to architecture, or, by analogy, external references helping him to 'adjectivize' designs with a great array of nuances or variations. Again, going back to their roots, there are three major formal sources sparking the redents' development over time. One is the tie to French tradition, be it military engineering in fortifications displayed in Eugène Hénard's boulevard à redans, the social reform, or the French garden.

Le Corbusier saw Hénard's designs for Paris even before his mentor's Perret reminded him of them. They were in the city planning exhibition Allgemeine Städtebau-Ausstellung 8 , held in Berlin in 1910 and including other designs by the most prestigious urban planners of the day from around the world. Jeanneret's visit to this exhibition left a deep mark on him and led him to depart from the tenets held in Camillo Sitte's book Der Städtebau nach seinen Künstlerischen Grundsätze published in 1889 (1980). Le Corbusier never carried through with his intention to complete it and the manuscript La construction des villes (Le Corbusier 1992) remained unfinished (Brooks 1985: 45; Émery 1987: 432-435). Le Corbusier did however use material he had prepared to prove an opposite point in Urbanisme (1925). Yet Sitte influenced him at least as much as Hénard did, not only during his years of training but also later on. Though it was diffuse, Sitte's influence can be deeply felt because Le Corbusier is one of the architects putting forward the modern city that was most reluctant to relinquish the closing of urban space. Obviously he did not proclaim this because it would run against his cause as the standard-bearer of modern architecture.

Insofar as the demarcation and size of urban space, in the manuscript, Jeanneret explains why squares are necessary and classifies them according to their purpose (Le Corbusier 1992: 101). These three purposes of the square were to be found later in his theoretical designs whose approach to urban space pooled from Sitte's visual facets. Unsurprisingly, the fourth section of the manuscript is devoted to plazas/squares. Sitte had already denounced the indiscriminate opening up of plazas/squares which he criticised as gigantism,

\footnotetext{
8 Exhibition published in Hegemann (1911-1913). The book in Le Corbusier's personal library is found with several handwritten notes he had made.
} 
not because of their size per se but rather because they were not on scale with the buildings along the perimeter. Le Corbusier agreed and devoted the fifth section of his manuscript to "enclosing walls", whose height should be proportionate to the expansion of the open space because "Un mur est évocateur de sentiments" (Le Corbusier 1992: 137).

In Urbanisme (1925), a publication that defended opposite ideas, Le Corbusier did not even deny the need for enclosures: "Cet homme seul en face de vastes étendues se lasserait. Il faut savoir resserrer le paysage urbain et inventer des éléments de mesure à notre échelle" (Le Corbusier 1925: 225). He merely sought an element to mediate between the large scale of the buildings: "L'arbre clôt le site trop vaste parfois; sa silhouette primesautière contraste avec la fermeté de ce que nos cerveaux ont conçu et que nos machines on fait" (Le Corbusier 1925: 225). The reinforcement of the horizontal-vertical proportion of urban space that enclosure brings with it implicitly can be found in the Ville radieuse's three dimensional urban planning confirming the bequeathal: "L'Urbanisme est une science à trois dimensions, indissolublement liées entre elles (et non pas à deux dimensions ainsi que le pratiquent les édiles et que l'enseignent les écoles). Tout ce qui intéresse la surface ne peut pas exister qu'en fonction directe de la hauteur. Ici est la clef même de toute solution" (Le Corbusier 1935: 198).

According to Ignasi Solà-Morales (1987: 136-139), the application of city's street-corridor inside buildings and the elimination of squares were to be the constant features of Le Corbusier's architecture. This seems exaggerated, and it seems more reasonable to believe that squares were to be reinterpreted in equivalent terms to streets. This article sustains that idea that squares remained present, and yet the increase in their size as well as that of the surrounding buildings, coupled with the emergence of nature, led these squares to be confused with parks and urban gardens and even the palaces from which they pooled. Le Corbusier did not create things from out of a cultural vacuum, but rather reinterpreted the past, as Alan Colquhoun rightly explains when he speaks of the configuration of buildings (Colquhoun 1978: 114). Le Corbusier himself adds "On me taxe aujourd'hui de révolutionnaire. Je vais vous confesser que je n'ai jamais eu qu'un maître: le passé; qu'une formation: l'étude du passé" (Le Corbusier 1930: 49).

If Le Corbusier's cities are made up of many parts, the same holds for his buildings. Using the components of a city, through his 'design for architecture' for which he compiled various materials of his own and others, Le Corbusier generated hybrid designs through mere juxtaposition. He was able to portray the evolution of each of the components as an organic development of an initial intent expressed in variations on a theme, or was able to have each component mutate towards a new theoretical form (Blasi, Padovano 1986: 190). Le Corbusier's building-types, that is, generic residential buildings, stem from combinations of open forms similar to the redents. In other words, both the origins and the development of all of his investigative work on the two theoretical cities resided was applied to the redents, and this can be observed in the open form origins of the immeubles-villas starting with an open form made up to segments (González Cubero 2012: 61). The fact that there is a plan with both half the lotissement (FLC31004A) (Fig. 23) and a full lotissement (FLC 31004B) is very telling of the way Le Corbusier's composed through plays on combined symmetries. And this is confirmed through duplication precisely symmetrical to the irregular park.

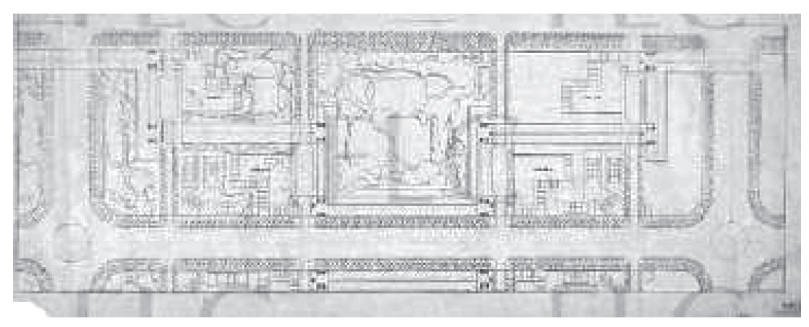

Fig. 23. Le Corbusier. Lotissements à redents. Half drawing of the lotissement (FLC31004A)

Hénard's faithfulness to Vauban's defensive ramparts was expressed in the boulevard à redents's conception of variety in order to avoid the monotonous uniformity of conventional streets. Laugier also made a statement in geometry through gardens and warned of the potential danger of too much regularity and symmetry in neighbourhoods, for which he put forward a solution: "Il faut pour cela posséder éminemment l'art des combinaisons" (Laugier 1979: 224). Shortly after leaving Berlin, Jeanneret used the combinations he learned in his classes with L'Eplattenier, based on the graphic constructions in Owen Jones' book The of Grammar of the ornament from 1856 (Allen Brook, 1999: 30), in a drawing in his Carnet 3. He simply used an illusionist procedure to generate double symmetry ornaments through a play on mirrors: "Lorsque l'on compose des ornements, emploi de 2 miroirs pour multiplier le motif./ II miroir/ 1 miroir"9 (Fig. 24). This amusing formal creation illustrates how Le Corbusier composed cities and theoretical buildings.

9 Le Corbusier. Carnet 3, September 28-October 21, 1910, in Le
Corbusier 2002: 119, [95] (100). 
While Adolf Loos so fiercely combatted ornaments superimposed on form (Loos 1993: 346-355), for Le Corbusier, ornaments became part and parcel of the form itself, i.e. the Greek patterned redent. The form was translated into different scales ranging from the

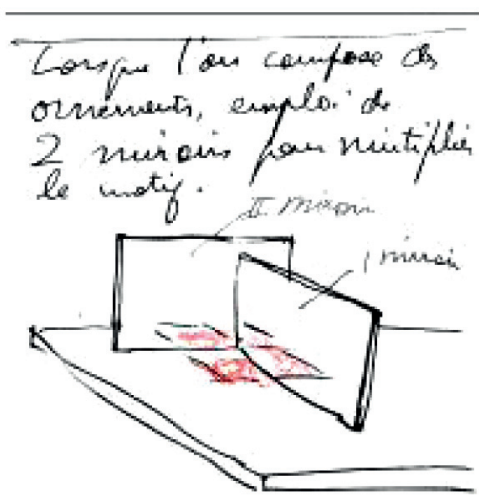

Fig. 24. Le Corbusier. Carnet 3, September 28 - October 21, 1910. A play on mirrors (FLC)

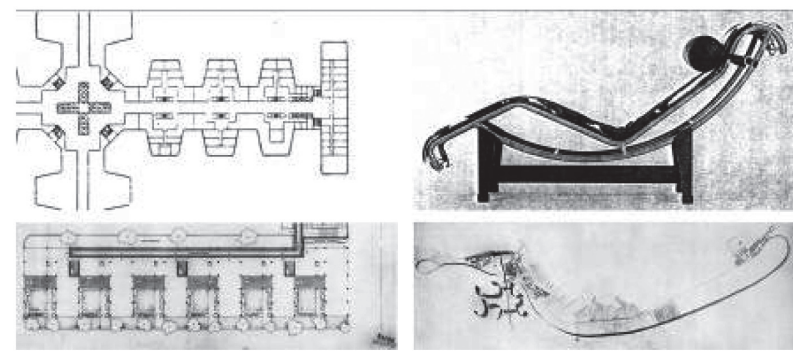

Fig. 25. Le Corbusier. The Greek patterned redent in gratteciel cartésien, immeubles-villas, chaise longue LC4 and Plan Obus, Algiers (FLC)

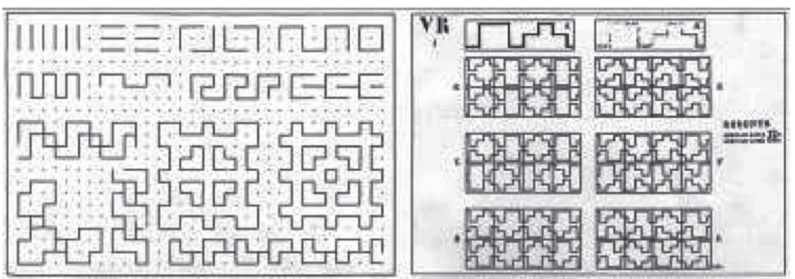

Fig. 26. Vuagnat's table (Neuchâtel) on Fröbel's exercise for the children's pedagogical system, and Le Corbusier's sector variations (VR1), Ville radieuse, 1930. Comparison done by Marc Solitaire
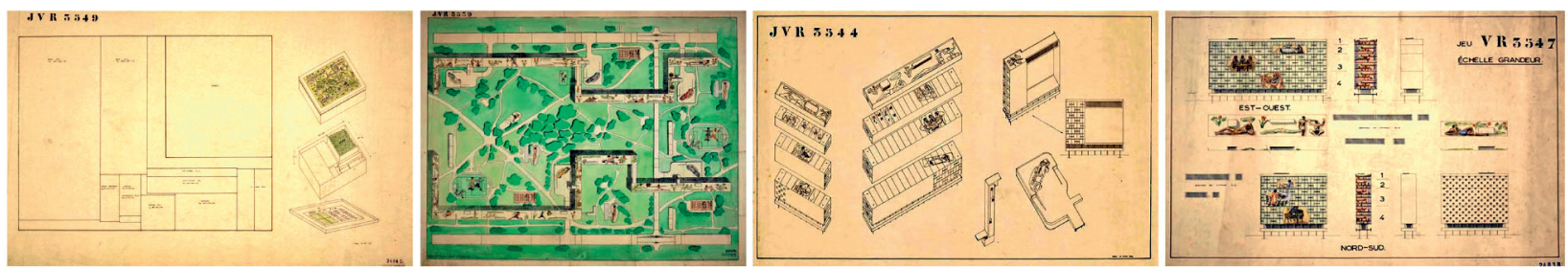

Fig. 27. Le Corbusier. The Ville radieuse board game, 1938-1951 (FLC) great arm of the gratteciel cartésien to the small folds on the plan in the zigzagging of the immeubles-villas, where open terraces were alternated with the closed volumes of front rooms, and in specific cases of functional adaptation to both organic forms and the landscape's acoustics, from the swivelling structure of the chaise longue to the redent in Algiers' Plan Obus (Fig. 25).

The redent was embedded in infancy through training with Friedrich Fröbel's pedagogical method based on games to develop personal creativity. Le Corbusier recommended this method for the sequence of nurseries, preschool buildings and primary schools (Le Corbusier 1987a: 308) set in the Ville radieuse's park within the redent. What better way to teach people to perceive his design than to use the very system that generated its forms?

Marc Solitaire's comparison (Solitaire 1993: 107) (Fig. 26) between Vuagnat's tables based on the pedagogical method and the redents in the Ville radieuse is indicative of an established model for creating and of an original pattern which would later find its justification in the history of architecture. Combinations of this original pattern give rise to polymorphic results expressed in a playful synthesis in the game applied to the Ville radieuse (Fig. 27). Perhaps for Le Corbusier, the redent, from its beginnings right up to the end, was merely child's play with its variations, combinations and permutations: "À Chandigarh, un soir, j'ai dit à Pierre Jeanneret: 'Il n'y a que ceux qui jouent qui soient des types sérieux!' "(Le Corbusier 1987b: 21).

In conclusion, Le Corbusier initially learned of the redent's geometric pattern as part of a game. He later consolidated it basing himself on Sitte's concept of urban space, and went on to reassert it with the principles of unity and diversity in Laugier's garden. This all fructified in various designs before Le Corbusier broke the redent up into Unités. As an architectural form, the redent pools from the designs drawn by his predecessors Fourier, Perret and Hénard and served as the backbone of his works on collective housing. The redent, whith the orthogonal, open and continuous form of its housing blocks, traces out an urban space that can be considered a street, square or park all at once. 
It stands as the last remaining element of historical cities in modern city designs. It is an inheritance that Le Corbusier's condensed cities apply and that history has been unable or unwilling to acknowledge.

\section{References}

Álvarez Álvarez, D. 2007. El jardín en la arquitectura del siglo XX. Barcelona: Editorial Reverté.

Blasi, C.; Padovano, G. (Eds.). 1986. Le Corbusier. La progettazione come mutamento. Milano: Mazzotta.

Brooks, A. H. 1985 [1982]. Jeanneret e Sitte: le prime idee di Le Corbusier sulla costruzione della città (Jeanneret and Sitte: Le Corbusier's Earliest Ideas on Urban Design), Casabella 514: 40-51.

Brooks, A. H. 1987. Jeanneret en la Chaux-de-Fonds. Los años de formación, in $A \& V$. Monografías de Arquitectura $y$ Vivienda 9: 6-13.

Brooks, A. H. 1999. Le Corbusier's formative years: CharlesÉdouard Jeanneret at La Chaux-de-Fonds. Chicago: University of Chicago Press.

Choay, F. 1970 [1965]. El urbanismo. Utopías y realidades (L'urbanisme. Utopies et realités). Barcelona: Lumen.

Cohen, J-L. 1987. Sulle trace di Hénard, Casabella 531-532 (gennaio-febbraio): 34-41.

Colquhoun, A. 1978 [1972]. Desplazamiento de conceptos en Le Corbusier, in Arquitectura moderna y cambio histórico. Ensayos: 1962-1976. Barcelona: Gustavo Gili, 113-126.

De Simone, R. 1989. Ch. É. Jeanneret-Le Corbusier. Viaggio in Germania 1910-1911. Roma: Officina.

Dézallier D’Argenville, A. J. 1972 [1709]. La Théorie et la Pratique du Jardinage. Hildesheim-New York: Georg Olms.

Émery, M-A. 1987. Premières réflexions: le manuscrit inédit de 'La Construction des villes', in J. Lucan (Ed.). Le Corbusier, une encyclopédie. Paris: Centre Georges Pompidou, 432 435

Hegemann, W. 1911-1913. Der Städtebau nach den Ergebnissen der allgemeinen Städtebau-Ausstellung in Berlin nebst einem Anhang: Die internationale Städtebau-Ausstellung in Düsseldorf. 2 vol. Berlin: Wasmuth.

Hénard, E. 1976 [1903]. Gli allineamenti interrotti. Il problema delle fortificazioni e il viale di circonvallazione (Les Alignements brisés. La question des Fortifications et le boulevard de Grande-Ceinture), Studi sulle trasformazioni di Parigi (Études sur les transformations de Paris), in D. Calabi and M. Folin (Eds.). Eugène Hénard. Alle origini dell'urbanistica: La costruzione della metropoli (1972). Padova: Marsilio, 61-79.

Fondation Le Corbusier. Paris, France.

Fourier, Ch. 1980 [1822]. Traité de l'Association domestique agricole, in Doctrina Social. El Falansterio. Madrid: Júcar.

Gargiani, R. 1993. Auguste Perret 1874-1954. Milano: Electa.

Giedion, S. 1982 [1941]. Espacio, tiempo y arquitectura. El futuro de una nueva tradición [Space, time and architecture: the growth of a new tradition]. Madrid: Dossat (in Spanish).

González Cubero, J. 2004. Sesión continua: Nómadas en el jardín. Ville contemporaine y Ville radieuse, in Massilia, 2004bis (Le Corbusier y el paisaje). Special Issue. Sant Cugat del Vallès: Associació d'Idees. Centre d'Investigacions Estètiques Sant Bartomeu- FLC, 70-95.
González Cubero, J. 2012. La paradoja de los immeubles-villas, in Ler Le Corbusier. Porto: Centro de Estudos Arnaldo Araújo da CESAP/ESAP.

Kroeber, A. L. 1948 [1923]. Anthropology. New York: Harcourt Brace Jovanovich.

Laugier, M. A. 1979 [1753-2 ${ }^{\text {nd }}$ ed. 1755, 1765]. Essai sur l'Architecture + Observations sur l'architecture, Bruxelles: Pierre Mardaga.

Le Corbusier [Jeanneret, Ch-É]. 2002 (1010-1911). Les voyages d'Allemagne. Milano-Paris: Electa-FLC.

Le Corbusier [Jeanneret, Ch-É]. 1992 (1910-1915). La construction des villes. Paris: L’Age d'Homme.

Le Corbusier (1914-1948) 1981. Le Corbusier Carnets 1 1914-1948. Paris-New York: The Architectural History Foundation, Herscher/ Dessain et Tolra.

Le Corbusier. 1923. Vers une architecture. $5^{\text {th }}$ ed. Paris: Crès.

Le Corbusier. 1924. L'Esprit nouveau 23 mai, n.p.

Le Corbusier. 1925. Urbanisme. $2^{\text {nd }}$ ed. Paris: Crès.

Le Corbusier. 1928. Une maison, un palais. Paris: Crès.

Le Corbusier. 1929. Le Corbusier Euvre complète 1910-29, in W. Boesiger, O. Storonov (Eds.). Zurich: Girsberger.

Le Corbusier. 1930. Précisions sur un état présent de l'architecture et de l'urbanisme. Paris: Crès.

Le Corbusier. 1987a [June 8, 1930]. Réponse à un questionnaire de Moscou, in J-L. Cohen (Ed.). Le Corbusier et la mystique de l'URSS. Théories et projets pour Moscou, 1928-1936. Bruxelles-Liège: Pierre Mardaga, 293-316.

Le Corbusier. 1934. Le Corbusier. Euvre complète 1929-1934, in W. Boesiger (Ed.). Zurich: Girsberger.

Le Corbusier. 1964 [1935]. La Ville radieuse. Paris: Vincent Fréal.

Le Corbusier. 1957 [1943]. Entretien avec les étudiants des écoles d'architecture. Paris: Minuit.

Le Corbusier. 1984 [1946]. Cómo concebir el urbanismo (Manière de penser l'urbanisme). Buenos Aires: Infinito.

Le Corbusier. 1946. Le Corbusier. Euvre complète 1938-46, in W. Boesiger (Ed.). Zurich: Girsberger.

Le Corbusier. 1950. L'Unité d'habitation de Marseille, Le Point 38 (novembre).

Le Corbusier. 1987b [1966]. Mise au point. Genève: Archigraphie.

Loos, A. 1993 [1908]. Ornamento y Delito (Ornament und Verbrechen), in Escritos I 1897-1909. Madrid: El Croquis Editorial, 346-355.

Oud, P. 1986 [1958]. Le Corbusier, in Mi trayectoria en "De Stijl". Murcia: Colegio Oficial de Aparejadores/ Galería-Librería Yerba, 126-131.

Panerai, Ph. R.; Castex, J.; Depaule, J-Ch. 1986 [1980]. Formas urbanas: de la manzana al bloque (Formes urbaines: de l'ilôt à la barre). Barcelona: Gustavo Gili.

Rowe, C. 1981 [1975]. Ciudad Collage (Collage City). Barcelona: Gustavo Gili.

Serenyi, P. 1975 [1967]. Le Corbusier, Fourier, and the Monastery of Ema, in P. Serenyi (Ed.). Le Corbusier in perspective. New Jersey: Prentice Hall, 103-116.

Sitte, C. 1980 [1889, 1965]. Construcción de las ciudades según principios artísticos (Der Städtebau nach seinen Künstlerischen Grundsätzen), in G. R. Collins and Ch. C. 
Collins (Eds.). Camillo Sitte y el nacimiento del urbanismo moderno. Barcelona: Gustavo Gili.

Solà-Morales, I. 1987. Nouveaux espaces dans la ville moderne, in Jacques Lucan (Ed.). Le Corbusier, une encyclopédie. Paris: Centre Georges Pompidou, 136-139.

Solitaire, M. 1993. Le Corbusier et l'urbain: la rectification du damier froebelien, in La Ville et l'Urbanisme après Le Corbusier. La Chaux-de-Fonds: Editions d'En Haut, 93-117.

Teyssot, G. 1981 [1967]. La casa per tutti: per una genealogia dei tipi, in R-H. Guerrand, G. Teyssot (Eds.). Les Origines $d u$ logement social en France. Roma: Officina.

\section{JOSEFINA GONZÁLEZ CUBERO}

Degree in Architecture in 1986. PhD in Architecture in 1996. Professor since 1997 in the Department of Architectural Theory and Design at the Technical School of Architecture, University of Valladolid, Spain. Her research interests include modernist and contemporary architecture, especially the works by Le Corbusier, and the relationship established between architecture and other arts. Coordinator of Architecture and Cinema Research Group and collaborator researcher in the Centro de Estudos Arnaldo Araújo, Porto, Portugal, since 2007. 